\title{
INTEGRASI MATERI PENDIDIKAN AGAMA ISLAM DAN PENDIDIKAN PANCASILA DAN KEWARGANEGARAAN DALAM MENANGKAL RADIKALISME
}

\section{Siti Muhayati}

Universitas PGRI Madiun Jawa Timur, Indonesia

Email: Sitimuhayati@unipma.ac.id

\section{Abstract}

NKRI is again a country where the establishment is the result of funds with citizens of the Republic of Indonesia whose religious background is different from each other. The purpose of this writing is to know the emergence of the beautiful and also the solution in the time of the emergence of people in the midst of their people. The focus of this research is the material of Islamic Religious Education, Pancasila Education and Citizenship that is internalized since the age of PAUD / TK, SD / MI, SMP / MTs, SMA / MA / Higher Education. A writer's author is a kind of research literature. Data or materials for which research is a good name book, articles in journals, articles on blogspot, articles in magazines, newsletters, reported in magazines, all data sing6 with the title of this study. Analyze the data by reducing, miserable, summarizing for solutions in the midst of the emergence of making beautiful beautiful. The results of his research directed that various parties both Akedemisi, The state with its laws and educational practitioners has emerged although it has sometimes still emerged, then with the integration of materials of Islamic Religious Education and Pancasila Education and Citizenship education level PAUD / TK / BA up to higher education can be another solution in countering radicals by means of a material Islamic Religious Education and Education Pancasila and Citizenship (Four Pillars of Nationality and the symbol of the state so the main material in Education and Citizenship) and internalize that the Four Pillars of Nationality part of the Islamic regulations results ijtihad scholars who have agreed, therefore Muslims do not dare to decorate.

Keywords: integration; theory; islamic education; pancasila and civic education; radicalism
Abstrak
NKRI adalah sebuah negara dimana berdirinya merupakan hasil kesepakatan bersama warga NKRI yang memiliki latar belakang agama yang berbeda satu dengan yang lain. Tujuan dari penulisan ini adalah untuk mengetahui pencegahan munculnya radikalisme dan menawarkan solusi tambahan dalam mencegah munculnya radikalisme. Fokus penelitian ini adalah mengamati materi Pendidikan Agama Islam, Pendidikan Pancasila dan Kewarganegaraan yang diinternaisasikanlkan sejak usia PAUD/TK, SD/MI, SMP/MTs, SMA/MA/ Perguruan Tinggi. Metode yang digunakan penulis adalah jenis penelitian literatur. Data atau bahan untuk menyelesaikan penelitian ini diambil dari buku, artikel di jurnal, artikel di blogspot, artikel di majalah, buletin, report di majalah, yang semua

$\begin{array}{ll}\text { How to cite: } & \text { Muhayati, Siti (2021) Integrasi Materi Pendidikan Agama Islam dan Pendidikan Pancasila dan } \\ & \text { Kewarganegaraan dalam Menangkal Radikalisme, 3(6). https://doi.org/10.36418/syntax idea.v3i6.1235 } \\ \text { E-ISSN: } & 2684-883 \mathrm{X} \\ \text { Published by: } & \text { Ridwan Institute }\end{array}$


data sesuai dengan judul penelitian ini. Analisa datanya dengan mereduksi, mengedit, meringkas membahas untuk menambahkan solusi dalam mencegah munculnya radikalisme kemudian ditarik kesimpulan. Hasil penelitiannya menunjukan bahwa berbagai pihak baik Akedemisi, Negara dengan sanksi hukumnya dan praktisi Pendidikan sudah mencegah munculnya walau sudah mereda tetapi sekali waktu masih muncul maka dengan integrasi materi Pendidikan Agama Islam dan Pendidikan Pancasila dan Kewarganegaraan dari tingkat pendidikan PAUD/TK/BA sampai dengan Perguruan Tinggi dapat menjadi solusi lain dalam menangkal radikalisme dengan cara mengintegrasikan materi Pendidikan Agama Islam dan Pendidikan Pancasila dan Kewarganegaraan(Empat Pilar Kebangsaan dan lambang negara sebagai materi pokok dalam Pendidikan dan Kewarganegaraan) dan menginternalisasikan bahwa Empat Pilar Kebangsaan bagian dari peraturan Islam sebagai hasil ijtihad ulama yang sudah disepakati, dengan begitu muslim tidak berani menghianati kesepakatan.

Kata Kunci: integrasi; materi; pendidikan agama islam; pendidikan pancasila dan kewarganegaraan; radikalisme

\section{Pendahuluan}

Radikalisme manampakan diri pada saat tertentu sebagai bukti bahwa ada sebagaian kecil muslim masih menginginkan peraturan Islam yang ada dalam Al Qur'an dan Al Hadits dijadikan peraturan positif dalam segala aspek kehidupan manusia termasuk dalam Negara Kesatuan Republik Indonesia (NKRI).

NKRI adalah sebuah negara dimana berdirinya merupakan hasil kesepakatan bersama warga NKRI yang memiliki latar belakang agama yang berbeda satu dengan yang lain (Arifin, Zainal, 2020) sedikitnya saat itu ada lima agama yang diakui oleh Negara, salah satunya adalah Islam.

Islam adalah agama yang dipeluk oleh mayoritas warga NKRI. Islam mengatur segala aspek kehidupan baik tata keimanan, tata norma atau peraturan, dan tata nilai perkataan dan perbuatan manusia. Termasuk dalam tata norma atau peraturan adalah hak dan kewajiban warga negara. Hak dan kewajiban warga negara dilandasi pada iman pada Allah dan peraturanNya, agar muslim dimana saja berada selalu mendatangkan rahmat bagi semua alam yaitu alam manusia, tumbuh tumbuhan, hewan dan lingkungan alam. Muslim sebagai warga NKRI juga berhak mendapat pendidikan Pancasila dan kewarganegaraan.

Pancasila adalah dasar falsafah NKRI yang wajib dipelajari, difahami, dihayati dan diamalkan oleh tiap warga NKRI. Kewaganegaraan adalah ikatan hukum antara negara dengan warganya yang menimbulkan hak dan kewajiban antara keduanya. Ilmu tentang kewarganegaraan ini juga wajib dipelajari, difahami, dihayati dan diamalkan oleh keduanya yaitu negara dan warga negaranya.

Islam, Pancasila dan kewarganegaraan merupakan peraturan yang harus dipelajari, difahami, dihayati, diamalkan dan tertanam pada diri tiap warga NKRI muslim dan non muslim sehingga antar warga negara mampu beinteraksi dengan baik, harmoni dan tolong menolong dalam kebaikan untuk membangun NKRI menjadi hunian yang aman 
tentram, damai, sejahtera, jauh dari curiga dan permusuhan. Oleh karena itu perlu adanya integrasi materi bahan ajar Pendidikan Agama Islam dengan Pendidikan Pancasila dan Kewarganegaraan tanpa memisahkan program studi Pendidikan Agama Islam, Pancasila dan Pendidikan Kewarganegaraan.

Integrasi materi atau bahan ajar Pendidikan Agama Islam dengan Pancasila dan Kewarganegaraan diharapkan radikalisme terkikis karena tidak ada kesalahfahaman antara Islam, Pancasila dan Kewarganegaraan. Dengan alasan ini maka penulis mengadakan penelitian literasi tentang Integrasi Pendidikan Agama Islam dengan Pendidikan Pancasila dan Kewarganegaraan. Pentingnya penelitian ini dilkukan untuk menambah solusi dalam mencegah munculnya radikalisme

Berbagai pihak sudah mengantisipasi munculnya radikalisme antara lain adalah praktisi pendidikan dengan membuat artikel dengan judul 1. Pencegahan Paham Radikalisme dan Terorisme Melalui Pendidikan Multukulturalisme pada Siswa MAN Kediri 1, artikel ini memberi solusi dengan cara memberi materi tentang wawasan kebangsaan yaitu nilai persatuan dan kesatuan, toleransi, multicultural, radikalisme dan terorisme. (Salim, Suryanto, \& Widodo, 2018) 2. Moderasi Kurikulum Perguruan Tinggi Islam Dalam Deradikalisasi Agama Di Indonesia. Artikel ini menawarkan solusi untuk menghalangi munculnya radikalisme dengan memoderasi kurikulum perguruan tinggi Islam dengan mengitegrasi semua ilmu dengan Islam; menampilkan teologi rahmatan lil'alamiin yang merupakan ciri Islam yang damai, penuh kasih sayang, anti kekerasan, menyapa semua manusia tanpa melihat latarbelakang budaya dan agama; mengharmonisasikan nilai nilai jawa dan nilai nilai Islam; membangun kurikulum anti radikalisme Perguruan Tinggi Islam; evaluasi pembelajaran yang berorientasi multikultural; program Pendampingan Pengembangan Kepribadian Muslim Integral; integritas nilai Pluralitas dalam kurikulum; metode pembelajaran yang multikulturalisme, (Ekawati \& Sirin, 2018)3. Selain kedua penelitian diatas, peneliti lain menyebutkan bahwa Mencegah Penyebaran Paham Radikalisme Pada Sekolah dengan cara proses pembelajaran dan diluar proses pembelajaran; memperkuat faktor pendukung strategi pencegahan dan penyebaran paham radikalisme dan melemahkan faktor penghambat pencegahan dan penyebaran paham radikalisme. (Sary, 2017), perbedaan dengan penelitian ini dengan hasil penelitian kesatu, kedua, dan ketiga diatas adalah peneliti hanya fokus pada meteri atau bahan ajar Pendidikan Agama Islam dan Pendidikan Pancasila dan Kewarganegaraan dimana ketiganya merupakan pedoman hidup manusia yang menjadi warga negara NKRI. Dan ketiganya diperkenalkan kepada peserta didik mulai usia Pendidikan anak Usia Dini Taman Kanak-Kanak (Raudatul Athfal), Sekolah Dasar (Madrasah Ibtidaiyah), Sekolah Menengah Pertama (Madrasah Tsanawiyah), Sekolah Menengah Atas (Madrasah Aliyah) dan Perguruan Tinggi (Umum dan Islam)

Pencegahan dan penyebaran paham radikalisme tidak hanya dilakukan oleh praktisi pendidikan tapi juga oleh negara. Asumsi dasar dari penulisan ini adalah integrasi materi Pendidikan Agama Islam dan Pendidikan Pancasila dan Kewarganegaraan mampu mencegah Radikalisme 
Fokus dari penulisan ini adalah integrasi materi atau bahan ajar Pendidikan Agama Islam dengan Pendidikan Pancasila dan Kewarganegaraan. Tujuan penulisan ini adalah untuk mengetahui integrasi materi atau bahan ajar Pendidikan Agama Islam dengan Pendidikan Pancasila dan Kewarganegaraan

Manfaat penulisan ini adalah untuk menambah wawasan warga NKRI dimana antar Islam, Pancasila dan Kewarganegaraan tidak ada pertentangan; Menambah iman dan taqwa muslim pada Allah dan peraturanNya yang sebagaian teruang dalam peraturan Sila Sila Pancasila dan dalam peraturan negara dalam segala aspek kehidupan; menambah wawasan luas bagi warga NKRI non muslim bahwa Pancasila dan Kewarganegaraanan bisa diintegrasikan pada agama yang mereka anut; menambah kreatifitas pendidik Pendidikan Agama Islam dan pendidik Pendidikan Pancasila dan Kewarganegaraan dengan penekanan pada peserta didik bahwa Pancasila dan Kewarganegaraan adalah salah satu peraturan Islam atau agama lain.

Kebaruan ilmiah tulisan ini adalah integriasi materi atau bahan ajar Pendidikan Agama Islam dan Pendidikan Pancasila dan Kewarganegaraan, sedangkan artikel diatas diintegrasikan dengan multidisiplin ilmu lain dimana perkataan dan perbuatan warga NKRI belum berdasarkan landasan yang kuat. Integrasi materi atau bahan ajar Pendidikan Agama Islam dan Pendidikan Pancasila dan Kewarganegaraan mampu mencegah radikalisme, karena perkataan dan perbuatan warga NKRI berdasarkan landasan yang kuat, dimana empat pilar kebangsaan (Pancasila, Undang Undang Dasar Negara. NKRI dan Bhinneka Tunggal Ika) merupakan hasil ijtihat ulama dengan begitu menjadi bagaian dari peraturan Islam, atau terintegrasi dengan Islam.

\section{Metode Penelitian}

Metode yang digunakan penulis adalah jenis penelitian literatur. Data atau bahan untuk menyelesaikan penelitian ini diambil dari buku, artikel di jurnal, artikel di blogspot, artikel di majalah, buletin, report di majalah, yang semua data sesuai dengan judul penelitian ini.

Analisa datanya adalah data yang terkumpul penulis analisa dengan mereduksi, mengedit, meringkas untuk mendapatkan data sebagai jawaban dari asumsi dasar dalam penelitian dan kemudian dibahas menambahkan solusi untuk pencegahan munculnya radikalisme dan ditarik kesimpulan.

\section{Hasil dan Pembahasan}

\section{A. Hasil Penelitian}

\section{Integrasi}

Integrasia dalah pembahuran sesuatu sehingga menjadi kesatuan yang utuh (Kamus Basar Bahasa Indonesia). Pembahuran ini bisa terjadi antara peraturan peraturan, baik peraturan yang berlaku dalam masyarakat maupun peraturan yang berupa peraturan positif, atau pembahuran fungsional antara fungsi yang ada pada lembaga lembaga di masyarakat atau pembahuran koersif karena memiliki kekuasaan, yaitu penyatuan antara wewenang dengan tindakan yang 
harus diambil oleh penguasa untuk menghentikan kerusuhan. Jadi integrasi adalah penyatuan perturan dari berbagai sumber peraturan, seperti peraturan agama disatukan dengan peraturan yang merupakan hasil ijtihad ulama tanpa mengurangi fungsi masing masing, atau penyatuan fungsi dari berbagai sumber yang mempunyai sumber, fungsi, atau penyatuan antara wewenang dengan tindakan yang harus diambil oleh penguasa untuk menyelesaikan suatu masalah.

Diantara integrasi tersebut adalah integrasi Materi Pendidikan Agama Islam dan Pendidikan Pancasila dan Kewarganegaraan. Materi Pendidikan merupakan salah satu dari faktor atau kompenen pendidikan, yang terdiri dari pengetahuan, ketrampilan dan sikap yang harus dikuasai peserta didik dalam rangka memenuhi standar kompetensi yang ditetapkan atau materi yang diajarkan dalam proses pembelajaran yang bertujuan agar peserta didik secara aktif mengembangkan potensi dirinya untuk memiliki kekuatan spiritual keagamaan, pengendalian diri, cerdas, akhlak mulia serta ketrampilan yang diperlukan dirinya, masyarakat, bangsa, dan negara kearah yang lebih baik lagi (Tabroni, 2020) Pendidikan yang diselenggarakan di lingkungan keluarga, sekolah dan masyarakat, ada syarat utama pemilihan materi pendidikan yang disampaikan pada peserta didik yaitu: materi harus sesuai dengan tujuan pendidikan; materi harus sesuai dengan peserta didik (Ihsa, 2011)

\section{Materi Pendidikan Agama Islam}

Salah satu materi pendidikana adalah Pendidikan Agama Islam. Pendidikan Agama Islam merupakan usaha sadar dan rencana yang dilaksanakan oleh orang dewasa pada peserta didik agar mampu mengembangkan potensi yang dibawa sejak lahir sehingga peserta didik beriman, bertaqwa, berwawasan luas cerdas, trampil, kreasi penuh inovasi yang kontruktif. Pendidikan Agama Islam merupakan salah satu faktor keberhasilan pendidikan sesuai dengan tujan pendidikan tersebut. Materi pendidikan agama Islam merupakan materi untuk menenambah wawasan tentang Islam termasuk didalamnya adalah sumber peraturan yang dijadikan pedoman hidup yaitu Pancasila dan Kewarganegaraan oleh warga NKRI, karena Islam itu seperangkat peraturan dimana peraturannya tidak hanya diambil dari Al Qur'an dan Al Hadits saja tapi juga hasil ijtihad. Diantara hasil ijtihad ulama adalah .Pancasila dan Undang Undang Dasar 1945 demikian juga NKRI dan Bhinneka Tunggal Ika. Islam membuat manusia hidup teratur, tentram damai sejahtera dimana manusia tersebut berada dibelahan dunia manapun. Islam seperangkat peraturan yang dibuat oleh Allah yang diajarkan oleh para nabi di berbagai tempat dan waktu mulai Nabi Adam sampai dengan Nabi Muhammad secara umum dan secara khusus Islam adalah seperangkat peraturan yang diajarkan oleh Nabi Muhammad Shalalloho 'alaihi wassalam.

Agama Islam mengatur segala aspek kehidupan manusia baik terkait tata keimanan (Iman dan taqwa atau aqidah); tata norma yaitu mengatur hubungan manusia dengan Allah, manusia dengan manusia, manusia dengan alam (syariah atau Islam dalam arti sempit); dan tata nilai untuk menilai perkataan perbutan 
dan sikap manusia. Secara garis besar materi Pendidikan Agama Islam adalah Aqidah, syareat dan akhlak yang tidak dapat dipisahkan karena aqidah adalah fondasi dari syariah artinya syariah dilaksanakan karena ada dasar hukum dari aqidah, jika syariah dilaksanakan atas dasar aqidah maka muncul akhlakul karimah atau mulia, dari akhlakul karimah atau mulia ini dapat diketahui kualitas perkataan, perbuatan dan sikap mnusia. Aqidah, syariah dan akhlak adalah ruang lingkup Pendidikan Agama Islam.

Tata keimanan dalam Islam (aqidah) adalah manusia iman kepada Allah, Malaikat, Kitab kitab Allah, Nabi dan Rasul Allah, Hari Akhirat, Qadla dan Qadar. Manusia diajak percaya pada kitab Allah, karena didalamnya ada peraturan Allah yang mengatur segala aspek kehidupan manusia. Peraturan tersebut disebut syariah.

Syariah atau juga dikenal dengan nama hukum Islam adalah peraturan Allah baik yang tercantum dalam Al Qur'an, Al Hadits dan hasil ijtihad ulama. Peraturan ini yang mengatur hubungan manusia dengan Allah, manusia dengan manusia, manusia dengan alam semesta. Salah satunya adalah peraturan tentang hubungan warga negara dengan negara.

Negara dalam perspektif Islam dengan mengacu negara Islam yang dipimpin oleh Nabi Muhammad dan sesudahnya yaitu masa khilafaur Rosyidin. Madinah merupakan suatu negara yang dipimpin oleh Nabi Muhammad juga memiliki hirarki sumber hukum negara, top learder, tiga kekuasan politik/lembaga kekuasaan, wilayah, warga negara (Anwari \& Nursikin, 2020). Secara garis besar Islam mengatur hubungan warga negara dengan negara, lembaga lembaga kekuasaan politik, peraturan peraturan yang telah disepakati bersama dan peraturan yang merupakan keturunan dari peraturan yang telah disepakati, karena peraturan itu semua merupakan hasil ijtihad ulama. Muslim dilarang untuk berhianat terhadap peraturan yang telah disepakati termasuk didalamnya empat pilar kebangsaan yang merupakan acuan hidup berbangsa dan bernegara muslim di NKRI. Muslim wajib menjadi warga NKRI yang baik dan wajib mendatangkan rahmatan lilalamiin.

Warga negara yang baik menurut Islam adalah warga negara yang bertuhan, toleransi, taat hukum, bekerja sama dalam kebaikan, berakhlakul karimah, zuhud, qanaah, syajaah. hilmun, iffah, bekerja keras, bekerja cerdas, bekerja tuntas, bekerja sesuai dengan standar operasional pekerjaan (SOP), shidiq, amanah, tbaligh, fathonah, sabar, tawakal dan ridlo.

\section{Materi Pendidikan Agama Islam di Berbagai Tingkat Pendidikan}

Warga NKRI membutuhkan Pendidikan Agama Islam agar menjadi warga negara yang baik yaitu materi Pendidikan Islam. tujuan tersebut tercapai jika materi Pendidikan Agama Islam disesuaikan dengan tingkat usia peserta didik. Materi pendidikan agama Islam sesuai dengan tujuan dan tingkat usia yaitu pada: Materi Pendidikan Agama Islam pada Pendidikan Anak Usia Dini (PAUD) dan Taman Kanak Kanak/ Bustanul Athfal (TK/BA). Materi 
pendidikan agama Islam untuk peserta didik pada PAUD tidak ada beda dengan materi untuk peserta didik pada TK.TK dapat diringkas sebagai berikut adalah: Aqidah (Keimanan). Materi Pendidikan Agama Islam di bidang aqidah didalamnya adalah iman kepada Allah, Malaikat, Kitab Allah, Nabi dan Rasul, Hari Kiamat, Qadla dan Qadar; Syari'ah (Ibadah). Materi Pendidikan Agama Islam di bidang ibadah peserta didik diperkenalkan tentang wudlu dan sholat baik teori maupun praktek; Akhlak (Budi Pekerti).Materi Pendidikan Agama Islam di bidang Akhlak peserta didik diperkenalkan berbuat baik pada semua orang baik dalam lingkup sempit maupun luas (Muthmainnah, 2017); Materi Pendidikan Agama Islam di PAUD/BA merupakan fondasi dasar dari Islam agar nantinya dikembangkan sesuai dengan usianya, begitu juga materi Pendidikan Agama Islam ditambahkan sesuai dengan usianya, sehingga terinternalisasi dengan mudah dan tidak terpengaruh hal yang didoktrin dalam waktu singkat guna merugikan diri sendiri, orang lain, Islam, bangsa dan negara.

Materi Pendidikan Agama Islam untuk peserta didik pada Sekolah Dasar/MI pada: Bidang Aqidah. Materi Pendidikan Agama Islam di bidang akidah masih terkait dengan iman kepada Allah dan segala sifat sifatNya dan iman kepada Nabi atau Rasul beserta nama namanya; Bidang IbadahMateri Pendidikan Agama Islam di bidang ibadah adalah terkait dengan wudlu, sholat dan membaca Al Qur'an; Bidang Akhlak. Materi Pendidikan Agama Islam di bidang Akhlak adalah terkait dengan kasih sayang Allah dan Nabi Muhammad kepada manusia, tentang kualitas diri seperti shidiq, amanh, tabligh fathonah, kerja keras, peduli lingkungan manusia, hewan dan alam lingkungan. Peserta didik mendapat porsi banyak dalam hal pembinaan akhlak pada Allah, manusia, dan lingkungan alam (Shunhaji, 2019). Materi Pendidikan Agama Islam untuk peserta didik pada SD/MI lebih ditekankan pada bidang akhlaq yaitu peserta didik memilikikarakter zuhud, qana'ah, syaja'ah, hilmun, iffah, kerja keras, istiqoamah/rajin, kerja cerdas, kerja tuntas, kerja sesuai Standar Operasional Pekerjaan (SOP), sabar, tawakal, ridlo akan qadla dan takdir Allah.

Materi Pendidikan Agama Islam untuk peserta didik pada Sekolah Menengah Pertama/Madrasah Tsanawiyah adalah Akidah.Materi Pendidikan Agama Islam untuk peserta didik pada Sekolah Menengah Pertama/Madrasah Tsanawiyah dalam bidang aqidah adalah Iman kepada Allah, Malaikat, Kitab Allah, Nabi dan Hari Akhirat. Ilmu.Makanan. Qurban, aqiqah, sejarah Islam; Syariah. Materi Pendidikan Agama Islam untuk peserta didik pada Sekolah Menengah Pertama/Madrasah Tsanawiyah dalam bidang Syariah adalah Toharoh, Shalat, Puasa, zakat, hajji Politik (Khalifah); Akhlaq.Materi Pendidikan Agama Islam untuk peserta didik pada Sekolah Menengah Pertama/Madrasah Tsanawiyah dalam bidang Syariah adalah Shidiq,amanah, istiqomah, birrul walidain, zuhud, qanaah. hilmun, iffah, syaja'ah, tawadlu', sabar, tawakkal, ridlo, adab penyembelihan hewan, tolearansi (Geograpik, 2020). 
Materi Pendidikan Agama Islam untuk peserta didik pada Sekolah Menengah Atas/ Madrasah Aliyah adalah Akidah.Materi Pendidikan Agama Islam untuk peserta didik pada Sekolah Menengah Atas/Madrasah Aliyah dalam bidang akidah adalah Asma'ul Husna, Malaikat Allah,Kitab Allah, Rasul Rasul Allah, Qadlao dan Qadar, Hari Akhir, Ilmu, Hidup dengan Kemuliaan; Syari'ah. Materi Pendidikan Agama Islam untuk peserta didik pada Sekolah Menengah Atas dalam bidang Syari'ah adalah Zakat, Haji, Waqaf, Ekonomi Islam, Pergaulan bebas dan zina, Masa Kejayaan Islam, Mawaris, Pengurusan Jenazah, Rumah Tangga; Akhlaq. Materi Pendidikan Agama Islam untuk peserta didik pada Sekolah Menengah Atas dalam bidang Akhlaq adalah Shidiq, Berbusana Muslim. Saling Menasehati, Menghormati Orang Tua dan Guru, Keragaman dan Demokrasi, Toleransi, Ihsan, Taat, Kompetensi, Etos Kerja, Dakwah Rasulullah di Madinah (Aladdiin \& PS, 2019); Sumber Hukum Islam Materi Pendidikan Agama Islam untuk peserta didik pada Sekolah Menengah Atas dalam bidang Hirarki Sumber Hukum Islam adalah Al Qur'an, Al Hadits, Ar Ro'yu, Pembaharuan Peraturan Islam sebagai hasil ijtihad Ulama (Negara, Dasar Negara, Undang Undang Dasar, Peraturan tentang Warga Negara), (Geograpik, 2020).

Materi Pendidikan Agama Islam untuk peserta didik pada Pergutruan Tinggi adalah Islam dikaitkan dengan isu isu kontemporer Islam dikaitkan dengan: Hak Asasi Manusia. Hak Asasi Manusia adalah Hak mendasar yang diperoleh manusia sejak lahir. Hak Asasi Manusia tersebut yaitu: Tiap manusia berhak memiliki Ruh, Akal Sehat, Harta, Silsilah, Agama dan nama baik; Demokrasi. Demokrasi adalah manusia diberi hak untuk membuat peraturan yang belum ditur oleh agamanya; Hukum.Hukum adalah peraturan yang mengatur segala aspek kehidupan manusia termasuk didalam peraturan yang berhubungan antara warga negara dan Negara; Sistem Politik.Sistem politik adalah tatacara mengelola negara dalam segala aspek kehidupan warga negaranya dan Negara; Masyarakat Madani.Masyarakat Madani adalah sosio plitik dimana didalamnya ada top leader, lembaga kekuasaan politik, wilayah, warga negra yang bertuhan, taat hukum dan berakhlakul karimah; Toleransi Antar Dan Intern Umat Beragama.Toleransi Antar Dan Intern Umat Beragama adalah toleransi antar umat beragama satu dengan umat beragama lain dan toleransi antar intern umat beragama dalam lingkup agama yang sama.

\section{Materi Pendidikan Pancasila Dan Kewarganegaraan}

\section{1) Materi Pendidikan Pancasila}

Materi Pendidikan Pancasila pada Pendidikan Anak Usia Dini dan

Taman Kanak Kanak/ Bustanul Athfal.Materi Pancasila pada Pendidikan Anak Usia Dini dan Taman Kanak Kanak/ Bustanul Athfal yaitu perkenalan tentang Lambang Negara, Bendera Negara, Lagu Kebangsaan, Bahasa Indonesia, Karakter Bangsa Indonesia yang mengacu pada nilai nilai Pancasila yaitu Iman dan Taqwa pada Tuhan Yang Maha Esa, 
Berprikemanusiaan, Cinta bangsa dan tanah air, Berjiwa demokrasi, Adil, jujur dan menolong orang lain (BPIP: 2)

Materi Pendidikan Pancasila pada Sekolah Dasar/Madrasah IbtidaiyahMateri Pendidikan Pancasila pada Sekolah Dasar/Madrasah Ibtidaiyah adalah penjabaran sila sila dalam Pancasila.Sila Pertama didalamnya Iman kepda Allah dan Asmaul Husna, Taqwa pada Allah dengan menjalankan perintahNya dan meninggalakan laranganNya.Toleransi dan Bebas menjalankan ibadahnya masing masing. Sila Kedua, didalamnya ada pengakuan, penghormatan dan perlindungan. Hak Asasi Manusia, Sila Ketiga didalamnya Persatuan, kesatuan dan keselamatan negara diatas kepentingan pribadi dan golongan, cinta tanah air dan pengakuan keberagaman suku, bangsa dan budya bangsa. Sila Keempat didalamnya kedaulatan negara ditangan rakyat, tiap manusia sama kedudukannya dihadapan hukum, musyawarah mufakat penuh persaudaraan, mengutamakan musyawarah dalam tiap mengambil keputusan. Sila Kelima, didalamnya mewujudkan keadilan dalam segala aspek kehidupan termasuk didalamnya politik, keseimbangan antara hak dan kewajiban, adil memberi pertolongan, bekerja sama dalam kebaikan, perpandangan futuristic (Rosyida, 2016).

Materi Pendidikan Pancasila pada Sekolah Menengah Pertama/Madrasah Tsanawiyah trintegrasi dengan Pendidikan Kewarganegaraan yaitu empat konsensus kebangsaan. Empat konesus tersebut adalah: a) Pancasila, sebagai dasar negara, ideologi nasional, dan pandangan hidup; b) Undang Undang Dasar Negara Republik Indonesia Tahun 1945 sebagai hukum dasar yang menjadi landasan konstitusional kehidupan bermasyarakat, berbangsa, dan bernegara; c) Negara Kesatuan Republik Indonesia, sebagai komitmen terhadap bentuk final Negara Republik Indonesia yang melindungi segenap bangsa dan tanah tumpah darah Indonesia; d) dan Bhinneka Tunggal Ika, sebagai wujud kesadaran atas keberagaman kehidupan bermasyarakat, berbangsa, dan bernegara yang utuh dan kohesif secara nasional dan harmonis dalam pergaulan antarbangsa (Maladi, 2018).

Materi Pendidikan Pancasila pada Sekolah Menengah Atas/Madrasah Aliyah terintegral dengan Pendidikan Kewarganegaraan yaitu membahas tentang Pancasila, Undang-Undang Dasar Negara Republik Indonesia Tahun 1945, Negara Kesatuan Republik Indonesia, dan Bhinneka Tunggal Ika. Peran Indonesia dalam Perdamaian Dunia, Mewaspadai Ancaman Terhadap Negara Kesatuan Republik Indonesia (Lubis, Yusnawan, 2017).

Materi Pendidikan Pancasila pada Perguruan Tinggi Umum/Perguruan Tinggi Islam adalah sejarah, kedudukan dan hakikat sila-sila Pancasila, merespon persoalan aktual bangsa dan negara, dan menerapkan nilai-nilai Pancasila dalam kehidupan (Nasional, Kebudayaan, \& Indonesia, 2012). 


\section{2) Materi Pendidikan Kewarga negaraan}

Materi Pendidikan Kewarganegaraan Materi Pendidikan Kewargaan Negara pada Pendidikan Anak Usia Dini dan Taman Kanak Kanak/ Bustanul Athfal adalah Negaraku, Alam Semesta, Pekerjaan dan Rekreasi (Istianti, Hamid, \& Abdillah, 2016)

Materi Pendidikan Kewarganegaraan pada Sekolah Dasar/Madrasah Ibtidaiyah adalah cinta tanah air, kasih sayang, cinta damai, kesetaraan, musyawarah, tanggung jawab, kemandirian, kejujuran dan rendah hati (Rosyida, 2016).

Materi Pendidikan Kewarganegaraan pada Sekolah Menengah Pertama/Madrasah Tsanawiyah trintegrasi dengan Pendidikan Pancasila yaitu empat pilar kebangsaan. Empat pilar tersebut adalah: a) Pancasila, sebagai dasar negara, ideologi nasional, dan pandangan hidup; b) Undang Undang Dasar Negara Republik Indonesia Tahun 1945 sebagai hukum dasar yang menjadi landasan konstitusional kehidupan bermasyarakat, berbangsa, dan bernegara; c) Negara Kesatuan Republik Indonesia, sebagai komitmen terhadap bentuk final Negara Republik Indonesia yang melindungi segenap bangsa dan tanah tumpah darah Indonesia; d) dan Bhinneka Tunggal Ika, sebagai wujud kesadaran atas keberagaman kehidupan bermasyarakat, berbangsa, dan bernegara yang utuh dan kohesif secara nasional dan harmonis dalam pergaulan antar bangsa (Maladi, 2018).

Materi Pendidikan Kewarganegaraan pada Sekolah Menengah Atas/Madrasah Aliyah terintegrasi dengan Pendidikan Pancasila yaitu membahas tentang Pancasila, Undang-Undang Dasar Negara Republik Indonesia Tahun 1945, Negara Kesatuan Republik Indonesia, dan Bhinneka Tunggal Ika. Peran Indonesia dalam Perdamaian Dunia, Mewaspadai Ancaman Terhadap Negara Kesatuan Republik Indonesia (Lubis, Yusnawan, 2017).

Materi Pendidikan Kewarganegaraan pada Perguruan Tinggi Umum/Perguruan Tinggi Islam adalah tentang konsep Hak Asasi Manusia, Demokrasi, Open society, order politik, sistem dan sejarah politik Indonesia.

\section{3) Radikalisme}

Radikalisme adalah gerakan berbasis Islam yang dimaksudkan untuk melakukan pembaruan dalam segala aspek kehidupan manusia yang dilakukan dengn cara drastis keras dan tanpa kompromi kepad pihak-pihak yang dianggap musuh, dengan satu prinsip bahwa hanya Syariat Islam saja yang mampu mengatasinya sehingga pendirian Negara Islam dan penerapan Syarit Islam menjadi ide perjuangan (Nurjannah, 2013).

Salah satu faktor munculnya radikalisme karena politik. Politik adalah cara mengelola negara. Politik dalam perbendaharaan istilah Islam disebut siyasah. Politik bagian dari peraturan Islam. Islam merupakan suatu sisitem 
politik yang mengatur hubungn manusia dengan Allah, manusia dan alam semesta. Selain Islam mengatur hubungan manusia dengan Allah, manusia dan alam juga mengatur hubungan muslim dengan non muslim yang diberi nama Piagam Madinah. Begitu sempurna Islam dalam segala peraturannya sehingga tidak ada alasan muslim untuk menjadi radikal dalam berbangsa dan bernegara. Faktor lain adalah muslim kurang memahami, menghayati dan mengamalkan Islam dan kurang fahamnya metode dakwah yang diamanatkan oleh Al Qur'an yaitu muslim mengajak manusia lain kejalan Allah dengan memberi pemahaman/hikmah/bimbingan, memberi mauidhoh hasanah bagaimana mengamalkan Islam, dan bersedia diajak berdialog dengan baik.

Disamping itu juga muslim yang terjebak pada radikalismre adalah anak yang mencari jati diri tentang keislamannya dan menemukan pembimbing yang berdakwah dengan kekerasan, rerata mereka usia peserta didik SMP/MTs, SMA/MA, perguruan tinggi umum, yang dari perguruan tinggi umum rerata mereka drop out.

Radikalisme sudah dicegah barbagai cara baik oleh Akademisi, Negara dan praktisi Pendidik, sudah mereda tapi kadang masih muncul juga, seperti pada tanggal 28 Maret 2021 pemboman gereja di Makasar dan teror penembakan di Mabes Polri pada tanggal 31 Maret 2021, maka dengan cara integrasi materi pendidikan Agama Islam dengan Pendidikan Pancasila dan Kewarganegaraan bisa lenyap sama sekali karena sudah tertanam dan terinternalisasi sejak dini bahwa Pancasila, Undang Undang Dasar 1945, NKRI, dan Bhinneka Tunggal Ika, dimana Pancasila, Undang Undang Dasar 1945, NKRI, dan Bhinneka Tunggal Ika terkenal dengan sebutan Empat Pilar Kebangsaan dan juga sebagai materi pokok dalam Pendidikan Pancasila dan Kewarganegaraan adalah hasil ijtihad ulama dan tidak bertentangan dengan Islam bahkan bagian dari ajaran Islam.

\section{B. Pembahasan}

\section{Integrasi Materi Pendidikan Agama Islam dan Pancasila dan Kewarganegaraan Dalam Menangkal Munculnya Radikalisme}

Pendidikan Agama Islam, Pendidikan Pancasila dan Pendidikan Kewarganegaraan bertujuan untuk membentuk warga negara NKRI beriman, bertaqwa, berwawasan luas, cerdas kreatif, penuh inovasi kontruktif, oleh karena itu ketiga materi pendidikan tersebut diintergrasikan dan diinternalisasikan dengan kuat pada tiap warga negara NKRI agar mampu menolak ajakan sepintas dari orang yang tidak bertanggung jawab atas keberlangsungan hidup pribadi, bangsa, dan negara. Adapun cara mengintegrasikan ketiga materi pendididkan tersebut dalam menangkal munculnya radikalisme disesuaikan dengan tingkat usia peserta didik. 


\section{Integrasi materi Pendidikan Agama Islam, Pendidikan Pancasila,} Pendidikan Kewarganegaraan pada Pendidikan Anak Usia Dini dan Taman Kanak Kanak/ Bustanul Athfal

Integrasi materi Pendidikan Agama Islam, Pendidikan Pancasila, Pendidikan Kewarganegaraan pada Pendidikan Anak Usia Dini dan Taman Kanak Kanak/ Bustanul Athfal dalam mencegah munculnya radikalisme dengan cara: mengintegrasikan Akidah dan Pancasila, Kewarganegaraan, NKRI, Undang Undang Dasar 1945, Bhinneka Tunggal Ika atau Empat Pilar Kebangsaan tersebut bagian dari akidah Islam kemudian diinternalisasikan pada peserta didik agar peserta didik sudah punya konsep bahwa Empat Pilar Kebangsaan tersebut diimani sebagaimana mengimani kitab Allah yang berisi peraturan Allah baik yang tercantum dalam Al Qur'an, Al Hadits dan Ar Ro'yu karena Empat Pilar Kebangsaan adalah hasil ijtihad ulama, masuk pada peraturan dari sumber Ar Ro'yu. Kemudian Empat Pilar Kebangsaan dan lambang negara diintegrasikan dengan materi Ibadah dalam Pendidikan Islam yaitu muslim mempunyai kewajiban untuk mengakui, menghormati dan melindungi Empat Pilar Kebangsaan, lambang Negara(Burung Garuda, Bahasa, Bendera dan bangsa). Selanjutnya sikap terhadap Empat Pilar Kebangsaan dan lambang negara diintegrasikan dengan akhlaq bahwa sikap menerima, mengamalkan dan mengimani Empat Pilar Kebangsaan merupakan akhlaqul karimah. Peserta didik usia PAUD/TK/BA sudah punya konsep seperti diatas jika pesreta didik sudah dewasa bersikap menolak radikalisme dari siapapun.

Guru mempunyai peran penting dalam menginternalisasikan integrasi materi Pendidikan Agama Islam dan materi Pendidikan Pancasila dan Pendidikan Kewarganegaraan maka guru Pendidikan Agama Islam wajib memiliki wawasan Empat Pilar Kebangsaan sehingga ketika menyampaikan materi pendidikan Pancasila dan Kewarganegaraan mampu totalitas mengintegrasi dengan Pendidikan Agama Islam. Sedangkan guru Pendidikan Pancasila dan Kewarganegaraan non muslim maka hendaklah mereka juga memiliki wawasan bahwa Empat Pilar Kebangsaan sebagai bagian dari peraturan Islam yang harus diterima, diakui, dihormati, dan dilindungi oleh peserta didik muslim, sehingga Empat Pilar Kebangsaan menginternalisasi pada peserta didik sebagaimana menginternalisasinya peraturan Islam yang lain, dan peserta didik mampu menolak radikalisme dari siapapun.

3. Integrasi materi Pendidikan Agama Islam, Pendidikan Pancasila, Pendidikan Kewarganegaraan pada Sekolah Dasar/Madrasah Ibtidaiyah

Integrasi materi Pendidikan Agama Islam, Pendidikan Pancasila, Pendidikan Kewarganegaraan pada Sekolah Dasar/Madrasah Ibtidaiyah dalam mencegah munculnya radikalisme dengan cara yang sama dalam mengintegrasikan materi Pendidikan Agama Islam dan Pendidikan Pancasila dan Kewarganegaraan sama dengan yang disampaikan pada peserta didik usia PAUD/TK/BA, karena materi Pendidikan Agama Islam dan materi Pendidikn Pancasila dan Kewarganegaraan 
dalam garis besar sama yaitu tentang akidah, syari'ah/ibadah, akhlak, dan Empat Pilar Kebangsaan dan lambang negara.

Pada tingkat SD/MI ada materi tambahan yaitu tentang menguatkan nilai Pancasila dimana muslim dalam melaksanakan rukun Islam sebagai pelaksanaan Sila Pertama dari Pancasila. Peran guru tetap dibutuhkan untuk mengintegrasikan materi tersebut pada tingkat pendidik SD/MI maka guru Pendidikan Agama Islam menambah wawasan dan diinternalisasikan pada peserta didik bahwa muslim menjalankan rukun Islam sama dengan melaksanakan Sila Pertama dari Pancasila, demikian juga guru Pendidikan Pancasila dan Kewarganegaraan non muslim menambah wawasan dan diinternalisasikan pada peserta didik bahwa muslim menjalankan rukun Islam sama dengan melaksanakan Sila Pertama dari Pancasila, sehingga peserta didik bersikap menolak radikalisme dari siapapun karena NKRI melindungi muslim melaksanakan agamanya.

4. Integrasi materi Pendidikan Agama Islam, Pendidikan Pancasila, Pendidikan Kewarganegaraan pada Sekolah Menengah Pertama/Madrasah Tsanawiyah

Integrasi materi Pendidikan Agama Islam, Pendidikan Pancasila, Pendidikan Kewarganegaraan pada Sekolah Menengah Pertama/Madrasah Tsanawiyah dalam mencegah munculnya radikalisme mencegah munculnya radikalisme dengan cara yang sama dalam mengintegrasikan Pendidikan Agama Islam dan Pendidikan Pancasila dan Kewarganegaraan pada peserta didik usia PAUD/TK/RA dan pada usia SD/MI. Pada tingkat SMP/MTs ditambah materi tentang hirarki sumber hukum Islam dan materi Pendidikan Pancasila dan Kewarganegaraan yaitu Empat Pilar Kebangsaan secara detail.

Peran guru tetap dibutuhkan untuk mengintegrasikan hirarki sumber hukum Islam dengan Empat Pilar Kebangsaan, maka guru harus menambah wawasan dan menginternalisasikan pada peserta didik bahwa Empat Pilar Kebangsaan merupakan bagian dari hirarki sumber hukum Islam ketiga karena hasil ijtihad ulama. Peraturan yang termuat dalam Empat Pilar Kebangsaan wajib ditaati oleh warganegara muslim selama peraturan tersebut tidak mengajak ma'shiat kepada Allah. Begitu juga guru Pendidikan Pancasila dan Kewarganegaraan non muslim menambah wawasan dan menginternalisasi pada peserta didik muslim bahwaEmpat Pilar Kebangsaan merupakan bagian dari hirarki sumber hukum Islam ketiga karena hasil ijtihad ulama. Peraturan yang termuat dalam Empat Pilar Kebangsaan wajib ditaati oleh warganegara muslim selama peraturan tersebut tidak mengajak ma'shiat kepada Allah, sehingga peserta didik bersikap menolak radikalisme dari siapapun.

5. Integrasi materi Pendidikan Agama Islam, Pendidikan Pancasila, Pendidikan Kewranegaraan pada Sekolah Menengah Atas/Madrasah Aliyah

tegrasi materi Pendidikan Agama Islam, Pendidikan Pancasila, Pendidikan Kewranegaraan pada Sekolah Menengah Atas/Madrasah Aliyah dalam menangkal munculnya radikalisme dengan cara yang sama dalam mengintegrasikan 
Pendidikan Agama Islam dan Pendidikan Pancasila dan Kewarganegaraan pada peserta didik usia PAUD/TK/BA dan pada usia SD/MI, pada SMP/MTs. Pada tingkat SMA/MA ditambah materi tentang Hak Asasi Manusia, Demokrasi, Peran Indonesia dalam Perdamaian Dunia, Mewaspadai Ancaman Terhadap Negara Kesatuan Republik Indonesia.

Peran guru dibutuhkan untuk mengintegrasikan Hak Asasi Manusia, Demokrasi, Perdamaian, dan politik dalam negeri dan luar negeri menurut Islam dan menurut rumusan NKRI. Maka guru Pendidikan Agama Islam harus menambah wawasan dan menginternalisasikan bahwa Hak Asasi Manusia, Demokrasi, Peran Indonesia dalam Perdamaian Dunia, Mewaspadai Ancaman Terhadap Negara Kesatuan Republik Indonesia merupakan bagian dari peraturan Islam. Guru Pendidikan Pancasila dan Kewarganegaraan non muslim juga menambah wawasan dan menginternalisasikan bahwa Hak Asasi Manusia, Demokrasi, Peran Indonesia dalam Perdamaian Dunia, Mewaspadai Ancaman Terhadap Negara Kesatuan Republik Indonesia merupakan bagian dari peraturan Islam sehingga peserta didik bersikap menolak radikalisme dari siapapun karena peraturan yang dirumuskan oleh NKRI adalah bagian dari peraturan Islam.

6. Integrasi materi Pendidikan Agama Islam, Pendidikan Pancasila, Pendidikan Kewarganegaraan pada Perguruan Tinggi Umum/Perguruan Tinggi Islam

Peserta didik di Perguruan Tinggi adalah peserta didik yang sudah mendapat fondasi agama Islam dan Pancasila dan Kewarganegaraan mulai dari PAUD/TK/BA, SD/MI, SMP/MTs, SMA/MA. Integrasi materi Pendidikan Agama Islam, Pendidikan Pancasila, Pendidikan Kewarganegaraan pada Perguruan Tinggi Umum/Perguruan Tinggi Islam, dengan cara mahasiswa diajak berfikir, merenung tentang memelihara, memajukan, memakmurkan dan menjadikan NKRI menjadi hunian yang aman, tentram, damai, sejahtera. Perbuatan itu semua merupakan bagian dari kewajiban agama Islam. Mahasiswa ditekankan dan diinternalisasikan bahwa, Pancasila, Undang Undang Dasar 1945, Negara Kestuan Republik Indonesia (NKRI), Bhinneka Tunggal Ika merupakan hasil ijtihad ulama dan tidak bertentangan dengan Islam atau dengan kata lain NKRI, Pancasila, Undang Undang Dasar 1945, Bhineka Tunggal Ika adalah Darul Mitsaq/Negara Kesepakatan (Ma'ruf Amin, 2019: 3). Mahasiswa ditekankan untuk mengisi NKRI dengan kemampuan dalam ilmu, teknologi dan seni agar NKRI cepat mencapai negara yang aman, adil, tentram damai dan sejahtera. 


\section{Kesimpulan}

Uraian dari pendahuluan sampai pembahasan dapat disimpulkan bahwa pencegahan munculnya radikalisme sudah dilakukan oleh berbagai pihak baik dari kalangan Akademisi, Negara dan praktisi Pendidik, walau sudah mereda tapi kadang masih muncul juga, seperti pada tanggal 28 Maret 2021 pemboman gereja di Makasar dan teror penembakan di Mabes Polri pada tanggal 31 Maret 2021; faktor muncul radikalisme antara lain adalah sistem politik NKRI, pelaku radikal kurang memahami, menghayati dan mengamalkan dan dakwah Islam, pelaku radikal masih mencari jati diri keislaman ; maka solusi lain menambah wawasan dengan cara Integrasi Materi Pendidikan Agama Islam dengan Pendidikan Pancasila dan Kewarganegaraan dapat mencegah radikalisme karena sejak dini Warga NKRI diinsternalisasikan bahwa Pancasila, Undang Undang Dasar 1945, Negara Kesatuan Republik Indonesia dan Bhinneka Tunggal Ika merupakan hasil ijtihad ulama dan tidak bertentangan dengan Islam bahkan bagian dari peraturan Islam, dengan begitu muslim tidak berani menghianati kesepakatan. 


\section{BIBLIOGRAFI}

Aladdiin, Hisyam Muhammad Fiqyh, \& PS, Alaika M. Bagus Kurnia. (2019). Peran Materi Pendidikan Agama Islam di Sekolah dalam Membentuk Karakter Kebangsaan. Jurnal Penelitian Medan Agama, 10(2).Google Scholar

Anwari, Misbakul, \& Nursikin, Mukh. (2020). Pembinaan Keagamaan untuk Meningkatkan Kecerdasan Spiritual Pada Santri Usia Lanjut di Pondok Pesantren Raden Rahmat Banyubiru Kabupaten Semarang. Jurnal Ilmiah Citra Ilmu, 16(32), 11-26. Google Scholar

Arifin, Zainal, Mardan Umar. (2020). Islam Rahmatan Lil'alamin, Mengenalkan Kelembutan dan Kasih Sayang Islam Kepada Generasi Milenial. Yogyakarta: Omah Ilmu.

Ekawati, Mundzier Suparta, \& Sirin, Khaerani. (2018). Moderasi Kurikulum Perguruan Tinggi Islam Dalam Deradikalisasi Agama Di Indonesia. Istiqro, 16(01), 139-178. Google Scholar

Geograpik. (2020). Materi Agama SMP Kelas 7, 8, 9, Terlengkap. Retrieved from https:geograpik.blogspot,com.

Ihsa, F. (2011). Dasar Dasar Kependidikan. Jakarta: Rineka Cipta.

Istianti, Tuti, Hamid, Solihin Ichas, \& Abdillah, Fauzi. (2016). Menelisik moral sosial kewarganegaraan dalam permainan pada pendidikan anak usia dini. Jurnal Moral Kemasyarakatan, 1(2), 86-96. Google Scholar

Lubis, Yusnawan, Mohamad Sodeli. (2017). Pendidikan Pancasila dan Kewarganegaraan / Kementerian Pendidikan dan Kebudayaan. Jakarta: Kementerian Pendidikan dan Kebudayaan.

Maladi, G. (2018). Penguatan Materi Pancasila dalam Kurikulum 2013. Widyaiswara PPPPTK PKn Dan IPS.

Muthmainnah, Muthmainnah. (2017). Kurikulum Pendidikan Agama Islam Taman Kanak-Kanak Islam Terpadu (Tkit) Al-Azhar Lamgugob Banda Aceh. Bunayya: Jurnal Pendidikan Anak, 1(2), 58-76. Google Scholar

Nasional, Departemen Pendidikan, Kebudayaan, Kementerian Pendidikan D. A. N., \& Indonesia, Republik. (2012). Materi Ajar Mata Kuliah Pendidikan Pancasila. Google Scholar

Nurjannah, Nurjannah. (2013). Faktor Pemicu Munculnya Radikalisme Islam Atas Nama Dakwah. Jurnal Dakwah, 14(2), 177-198. Google Scholar

Rosyida, Desy Anindia. (2016). Pembelajaran Pendidikan Kewarganegaraan MI dalam Meningkatkan Karakter Siswa Berbasis Tradisi Pesantren. Muallimuna, 1(2), 62- 
Integrasi Materi Pendidikan Agama Islam dan Pendidikan Pancasila dan Kewarganegaraan dalam Menangkal Radikalisme

\section{Google Scholar}

Salim, Nur, Suryanto, Suryanto, \& Widodo, Agus. (2018). Pencegahan Paham Radikalisme dan Terorisme Melalui Pendidikan Multikulturalisme pada Siswa MAN Kediri I. Jurnal ABDINUS: Jurnal Pengabdian Nusantara, 2(1), 99-107. Google Scholar

Sary, Noermala. (2017). Mencegah Penyebaran Paham Radikalisme Pada Sekolah. Manthiq, 2(2), 191-200. Google Scholar

Shunhaji, Akhmad. (2019). Agama dalam Pendidikan Agama Islam di Sekolah Dasar. Andragogi: Jurnal Pendidikan Islam Dan Manajemen Pendidikan Islam, 1(1), 122. Google Scholar

Tabroni, G. (2020). Pendidikan: Pengertian, Unsur, Tujuan, Fungsi, dsb (Lengkap).

\section{Copyright holder :}

Siti Muhayati (2021)

First publication right :

Jurnal Syntax Idea

This article is licensed under:

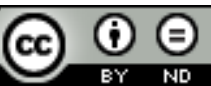

